\title{
EFFECT OF FIRE ON FLOWERING AND FRUITING OF Anacardium humile (ANACARDIACEAE) IN CERRADO stricto sensu ${ }^{1}$
}

\author{
Diego Guimarães de Sousa ${ }^{2 *}$ and Hélida Ferreira da Cunha ${ }^{3}$
}

\footnotetext{
${ }^{1}$ Received on 03.05.2018 accepted for publication on 23.10.2018.

${ }^{2}$ Instituto Brasileiro de Meio Ambiente e dos Recursos Naturais Renováveis, Goiânia, GO-Brasil. E-mail:<diegoagro97@hotmail.com>.

${ }^{3}$ Universidade Estadual de Goiás, Unidade Universitária, Anápolis, GO-Brasil. E-mail: <cunhahf@gmail.com>.

*Corresponding author.
}

\begin{abstract}
Knowledge about the effects of fire on sexual reproduction of Cerrado woody species is fundamental for elaborating public policies and management plans for its conservation. The present study evaluated the effect of a controlled burning on flowering and fruiting of Anacardium humile in an Cerrado stricto sensu environment, in Cavalcante, GO. An area with no fire records for five years was submitted to controlled burning in May 2016, used as the experimental area and its adjacent areas protected from fire as control area. In each area, 16 reproductive individuals were selected and their production of floral buds, flowers and fruits, followed up for 17 months. In 2016 the production of reproductive structures was higher in the control area, since the majority of individuals of the burned area invested in the recovery of vegetative structures (branches) damaged by fire. Only three individuals flowered in the burned area in 2016 and presented greater effort in the production of buds and flowers per panicle than the individuals in the control area, however, the fruit set was equal between the areas. One year after fire, the production of reproductive structures became equal between areas. The control area presented higher fruit production in $2017 \mathrm{in}$ comparison to 2016 , indicating a variable pattern in annual fruit production. The impact of fire on the reproductive structures of $A$. humile is greater in the same year of fire and its reproductive potential can be normalized in the subsequent year.
\end{abstract}

Keywords: Controlled burning; Reproductive phenology; Fruiting rate.

\section{EFEITO DO FOGO NA FLORAÇÃO E FRUTIFICAÇÃO DE Anacardium humile (ANACARDIACEAE) EM CERRADO stricto sensu}

\begin{abstract}
RESUMO - O conhecimento acerca dos efeitos do fogo na reprodução sexual das espécies lenhosas do Cerrado é fundamental para a elaboração de políticas públicas e de ferramentas de manejo para a sua conservação. O presente estudo avaliou o efeito de uma queima controlada na floração e frutificação de Anacardium humile em ambiente de cerrado sentido restrito, em Cavalcante, GO. Uma área sem registro de fogo há cinco anos foi submetida a queima controlada em maio de 2016 e utilizada como área experimental e suas adjacências protegidas do fogo como áreas controle. Em cada área, 16 indivíduos reprodutivos foram selecionados e sua produção de botões florais, flores e frutos, acompanhada por 17 meses. Em 2016 a produção de estruturas reprodutivas foi maior na área controle, uma vez que a maioria dos individuos da área queimada investiu na recuperação das estruturas vegetativas (ramos) danificadas pelo fogo. Apenas três indivíduos floresceram na área queimada em 2016 e apresentaram maior esforço na produção de botões e flores por panícula do que os da área controle, todavia, a taxa de frutificação foi igual entre as áreas. Um ano após a queima a produção das estruturas reprodutivas tornou-se igual entre as áreas. A área controle apresentou maior produção de frutos em 2017 comparada a 2016, indicando padrão variável na produção anual de frutos. O impacto do fogo nas estruturas reprodutivas de A. humile é maior no mesmo ano de queima e seu potencial reprodutivo pode ser normalizado no ano posterior.
\end{abstract}

Palavras-Chave: Queima controlada; Fenologia reprodutiva; Taxa de frutificação. 


\section{INTRODUCTION}

The biome Cerrado has been living with fire for more than 32,000 years (Salgado Laboriau and FerrazVicentini, 1994), with natural fires due to the action of rays occurring at late dry season and during rainy season (Ramos Neto and Pivello, 2000). However, in recent history the fire frequency has been significantly altered due to the anthropogenic actions, contributing to increasing the degradation of this biome considered one of the great world biodiversity hotspots (Myers et al., 2000; Fiedler et al., 2004). Fires can affect flowering and fruiting (Miranda, 1995; Sanaiotti and Magnusson, 1995; Miola et al., 2010; Palermo and Miranda, 2012; Françoso et al., 2014; Deus et al., 2016; Sato et al., 2018), including pollinators richness and abundance (Giehl et al., 2013; Deus et al., 2016), seed dispersion, recruitment and mortality rates of several species (Miranda and Sato, 2005; Medeiros and Miranda, 2005; Cirne and Miranda, 2008; Bouchartdet et al., 2015) especially in the driest months (Costa and Rodrigues, 2015).

Knowledge about the effects of fire on the sexual reproduction of woody species is still poor regarding the rich and complex diversity of the Cerrado (Miranda and Sato, 2005; Palermo and Miranda, 2012). Even species that share characteristics of size and growth forms may present different responses to fire on their reproductive phenology (Sanaiotti and Magnusson, 1995; Dodonov et al., 2018), even though habit and being deciduous favor common patterns of plant phenological responses to fire (Miranda, 1995; Lucena et al., 2015). Moreover, contrary to what is observed in other flammable ecosystems around the world, in the Cerrado-forest mosaic, seed germination is not directly linked to the presence of fire (Andrade, 2017), corroborating that there is no way to generalize the effect of fire on the Cerrado species.

Understanding the reproductive behavior of the Cerrado's woody plants when burned is fundamental for the development of strategies for species conservation and constitutes a priority information for the elaboration and implementation of a national fire policy, using fire as a tool for conservation in public and private areas (Durigan and Ratter, 2016). In fact, prescribed burning that consist of the application of carefully controlled fires, with defined climatic conditions and fuels for lands management or ecological objectives, involving a written plan, or even a controlled burning to eliminate or reduce fuel to control the spread of fire in sensitive ecosystems (Myers, 2006), is one of the available tools that makes it possible to reproduce the appropriate role of fire in the maintenance of Cerrado species. For using fire in the Cerrado conservation, research about its effect on biota is necessary, where some adaptive characteristics have been identified, as well as adverse effects derived from the current fire regime (Medeiros and Fiedler, 2004). Moreover, such research should be carried out at sites with a higher frequency of wildfires and in different floristic compositions, encompassing effects on the fauna (Arruda et al., 2018), using multiple variables and evaluating their effects at the biome level in long-term experiments (Gomes et al., 2018).

The present study aimed to evaluate the effect of fire on flowering and fruiting of Anacardium humile specimens, comparing the response of individuals located in an area of Cerrado stricto sensu submitted to controlled burning at early dry season with the response of individuals in adjacent areas protected against fire for five years.

\section{MATERIALS AND METHODS}

\subsection{Study species}

Anacardium humile A.St.-Hil. (Anacardiaceae) is a heliophilous and melliferous plant (Almeida et al., 1998) that frequently occur in Campo rupestre and Cerrado stricto sensu areas (Agostini-Costa et al., 2016). The species reaches between 30 to $150 \mathrm{~cm}$ high and presents a shrubby and subshrubby habit with underground stem (Almeida et al., 1998; Sousa and Cunha, 2018). The small size makes the species more susceptible to anthropogenic actions of land use and damages by fire flames than the common cashew (Anacardium occidentale L.) (Carvalho et al., 2005). On the other hand, A. humile has deep roots and the greater portion of the plant stem biomass is underground, providing protection and resistance to fire and drought (Agostini-Costa et al., 2016), frequent in burned environments (Loiola et al., 2010). This plant present medicinal and food potential, placed in the tropical fructiferous group (Carvalho et al., 2005). In the literature, there are many studies on population biology of the genus Anacardium, but few regarding $A$. humile (Sousa and Cunha, 2018). This lack of studies shows the possibility of researches aiming preservation strategies planning using this species (Carvalho et al., 2005).

Revista Árvore. 2018;42(6):e420605 


\subsection{Study area}

This study was performed in Cerrado stricto sensu environment within the Quilombola Community Kalunga (QCK), municipality of Cavalcante, northern Goiás (geographical coordinates $13^{\circ} 36^{\prime} 09^{\prime \prime} \mathrm{S}$ e $47^{\circ} 27^{\prime} 26^{\prime \prime} \mathrm{W}$ ). The climate is tropical savanna (Köppen-Geiger classification), with two defined seasons, one rainy between October and April and another dry between May and September. The altitude varies between 560 $\mathrm{m}$ to $1118 \mathrm{~m}$, annual mean precipitation and mean temperature is around $25^{\circ} \mathrm{C}$ (Fundação Grupo Boticário, 2011). Soil is sandy with rocky outcrops and gravel, classified as Dystrophic Litholic Neosols (Embrapa, 2006; Fundação Grupo Boticário, 2011).

The Instituto Brasileiro de Meio Ambiente e dos Recursos Naturais Renováveis (IBAMA) started in 2015 the Integrated Fire Management (IFM) in the QCK, through the Centro Nacional de Prevenção e Combate aos Incêndios Florestais (PREVFOGO). Thus, in April 2016, in concordance with action of IBAMA/PREVFOGO, we subdivided a non-burned area for at least five years, with same population of $A$. humile, in two: first area of about three hectares was submitted to controlled burning on May 14, 2016, being the experimental area; and the other, with more than 30 hectares, comprising adjacent areas to the burned area, remained protected against fire, being the control area.

\subsection{Phenological monitoring and statistical analysis}

The methodology used in the present study was based on Palermo and Miranda (2012) with some modifications. Eleven days before the controlled burning in May 2016, we selected and marked 32 reproductive individuals, 16 in each area. Although the control area was larger than the experimental area, individuals were selected within a maximum radius of $500 \mathrm{~m}$ from those located in the burned area. The individuals were considered as reproductive when they still had remnants of inflorescence emerged in the previous reproductive season. Considering that the species has an underground stem that can bind together with close stems of the same plant (Rawitscher et al., 1943), we only considered individuals with a minimum distance of $1 \mathrm{~m}$ between the ends of their crowns, with emission of branches at the same point, visually configuring the unitary structure of shrub or subshrub. To evaluate the effect of fire on the species reproductive structures, the production of floral buds, flowers and fruits was monitored weekly for 17 months after the controlled burning (from May 2016 to October 2017), comprising two reproductive seasons. Up to three branches per selected individual were marked, observing the appearance of panicles. Each panicle was marked and the count started when the buttons were differentiable. Every new reproductive cycle, new branches and panicles were marked. We also counted the number of individuals blooming in each area, as well as the number of flower buds, flowers and fruits per area and per panicle area $^{-1}$.

Statistical analysis was performed using non-parametric tests, since data did not respond to normality. Similar to Palermo and Miranda (2012), the G test $(\alpha=0.05)$ was used to compare the number of blooming individuals in each area and $\mathrm{x}^{2}(\alpha=0.05)$ to compare the number of independent branches that produced panicles and the number of panicles per area. The production of flower buds, flowers and fruits per area and panicle were compared using the KruskalWallis test $(\alpha=0.05)$ and the post hoc Student-NewmanKeuls (SNK) test. Statistical analyzes and tests were performed in the R (R Core Team, 2016) software using the agricolae package (Mendiburu, 2016). Local precipitation data were obtained through a rain gauge (pluviometer) installed in the study area to compose the production charts of flower buds, flowers and fruits.

\section{RESULTS}

From May to October 2016, the number of $A$. humile individuals producing flowers was significantly higher in the control area $(n=12)$ than in the burned area $(n=3)$ $(G=10.799 ; p=0.001)$. The number of branches with panicles was higher in the control area $(n=22)$ than in the burned area $(n=7)\left(x^{2}=7.759 ; p=0.005\right)$. More panicles were produced in the control area $(n=40)$ than in the burned area $(n=7)\left(x^{2}=23.17 ; p<0.0001\right)$.

The production of floral buds was significantly higher in the control area $(n=4540)$ than in the burned area $(n=$ 704) $(\mathrm{p}<0.05)$ (Figure 1). From the buds emerged in each area, 257 end up flowering in the burned area and 1236 in the control area, evidencing higher production in the latter $(p<0.05)$ (Figure 2$)$. The production of fruits was higher in the control area (about nine fruits) than in the burned area that presented only one fruit $(p<0.05)$ (Figure 3) (Table 1). Individuals in the control area started flowering in May and finished fruiting one month before those in the burned area (September), while in the burned area, the few individuals bloomed in the short period from August to October. 


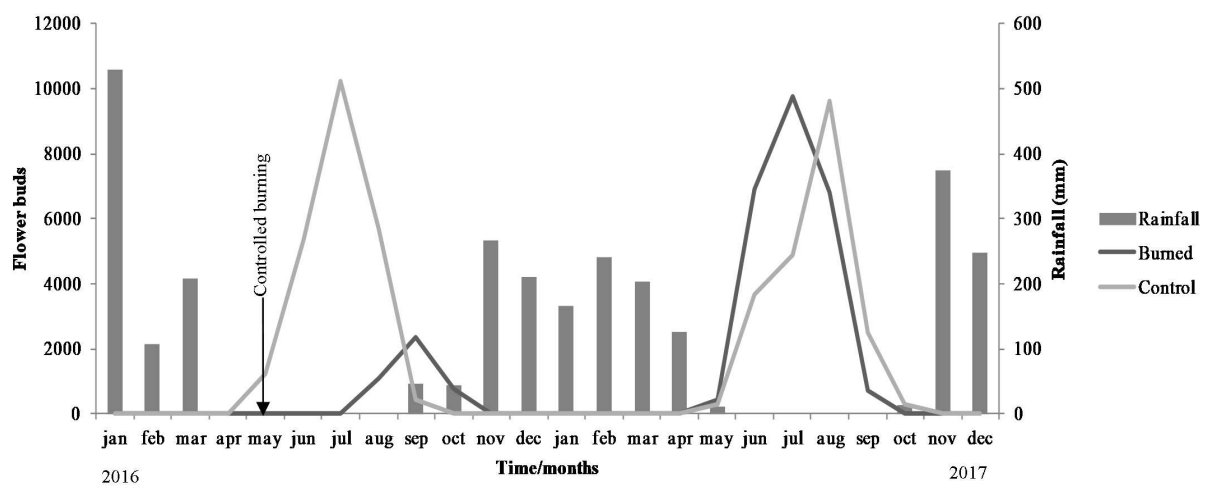

Figure 1 - Production of Anacardium humile floral buds in control and burned areas.

Figura 1-Produção de botões florais de Anacardium humile nas áreas controle e queimada.

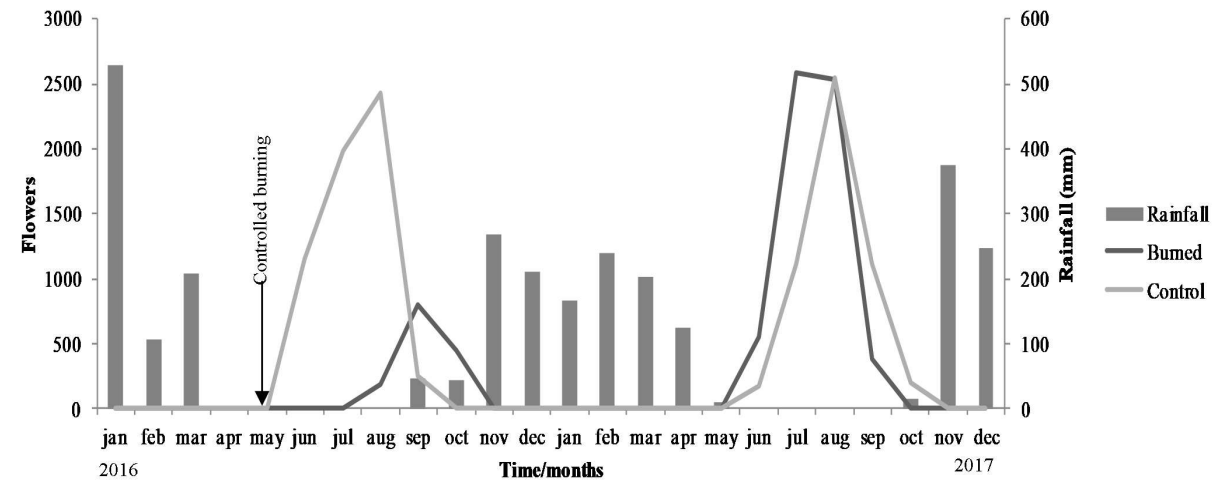

Figure 2 - Production of Anacardium humile flowers in control and burned areas

Figura 2 - Produção de flores de Anacardium humile nas áreas controle e queimada.

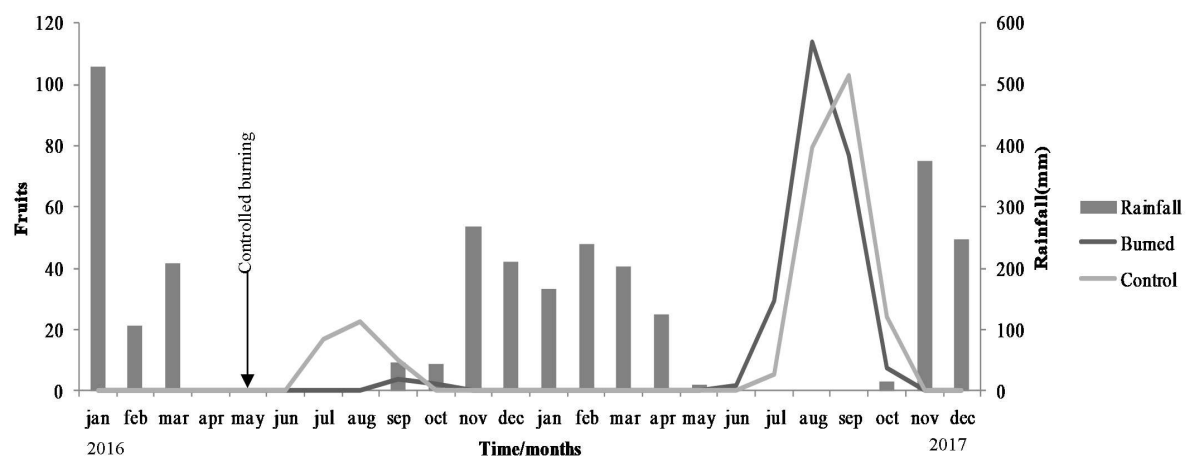

Figure 3 - Production of Anacardium humile fruits in control and burned areas.

Figura 3 - Produção de frutos de Anacardium humile nas áreas controle e queimada.

Revista Árvore. 2018;42(6):e420605 
Table 1 - Production of buds, flowers and fruits (mean \pm standard error) of Anacardium humile. Capital letters compare two periods of the same area and lowercase letters, two areas in a same period. Values followed by different letters presented significant differences $(\mathrm{p}<0.05)$.

Tabela 1 - Produção de botões, flores e frutos (média \pm erro padrão) de Anacardium humile. Letras maiúsculas comparam dois períodos de uma mesma área e letras minúsculas, duas áreas em um mesmo período. Valores seguidos de letras diferentes apresentam diferenças significativas $(p<0,05)$.

\begin{tabular}{lcccc}
\hline & \multicolumn{2}{c}{2016} & Control & 2017 \\
\hline & Control & Burned & Burned & \\
Buds & $4540.27 \pm 870.16 \mathrm{a}, \mathrm{A}$ & $703.77 \pm 235.44 \mathrm{~b}, \mathrm{~A}$ & $2639.39 \pm 545.34 \mathrm{a}, \mathrm{A}$ & $3220.91 \pm 783.17 \mathrm{a}, \mathrm{B}$ \\
Flowers & $1235.83 \pm 275.36 \mathrm{a}, \mathrm{A}$ & $256.55 \pm 91.69 \mathrm{~b}, \mathrm{~A}$ & $742.61 \pm 165.86 \mathrm{a}, \mathrm{A}$ & $937 \pm 236.03 \mathrm{a}, \mathrm{B}$ \\
Fruits & $9.5 \pm 1.93 \mathrm{a}, \mathrm{A}$ & $1.05 \pm 0.38 \mathrm{~b}, \mathrm{~A}$ & $32.90 \pm 10.03 \mathrm{a}, \mathrm{A}$ & $37.35 \pm 10.40 \mathrm{a}, \mathrm{B}$ \\
\hline
\end{tabular}

When analyzing the average flower bud and flower production per panicle area $^{-1}$, we noticed a higher production in the burned area than in the control area (Table 2). Flower buds to flowers transformation rate was higher in the burned area, approximately $37 \%$, than in the control area, which presented $27 \%(p<0.05)$. However, despite having panicles with higher number of buds and flowers, and greater buds to flowers transformation in the burned area, the average production of fruits per panicle did not differ between areas ( $>0.05$ ). The fruiting rate per panicle was the same between the areas ( $p>0.05)$, with buds to fruits transformation ranging from $0.15 \%$ to $0.20 \%$ and flowers to fruits between $0.42 \%$ and $0,73 \%$ (Table 2 ).

In the next year after the fire, from May to October 2017 , there were no differences in the number of individuals flowering between the burned $(\mathrm{n}=13)$ and control areas $(n=11)(G=0.6722, p=0.4123)$. There were also no significant differences in the number of branches with panicles $\left(x^{2}=2.683, p=0.1015\right)$ and number of panicles $\left(x^{2}=0.309\right.$, $\mathrm{p}=0.5785)$ in the control ( 25 branches and 38 inflorescences) and burned areas ( 38 branches and 43 panicles).
There were no significant differences in the production of flower buds, flowers and fruits between the burned and control areas (Table 1). The average production of flower buds, flowers and fruits per panicle also did not differ significantly between the areas. The buds to flowers transformation rate was about $29 \%$ in both areas. The fruiting rate per panicle was also the same between the areas ( $p>0.05)$, with total number of fruits representing between $1.15 \%$ and $1.25 \%$ of the buds emerged and approximately $4 \%$ of the flowers (Table 2).

When comparing the two flowering periods in 2016 and 2017 , the number of flowering individuals $(\mathrm{G}=$ $13.4765, \mathrm{p}=0.0002)$, the number of branches with panicle $(\mathrm{x} 2=21.356, \mathrm{p}<0.0001)$ and the number of panicles $\left(\mathrm{x}^{2}=25.92, \mathrm{p}<0.0001\right)$ increased in the burned area. Regarding the control area, there was no difference in the number of flowering individuals $(\mathrm{G}=0.1548$, $\mathrm{p}=0.6940)$, number of branches with panicle $\left(\mathrm{x}^{2}=0.191\right.$, $\mathrm{p}=0.6617)$ and number of panicle between the years $\left(\mathrm{x}^{2}=0.051, \mathrm{p}=0.8208\right)$.

Table 2 - Production of buds, flowers and fruits (mean \pm standard error) by inflorescence of Anacardium humile. Buds to Flowers $(\mathrm{B} / \mathrm{F})$, buds to fruits $(\mathrm{B} / \mathrm{Fr})$ and flowers to fruits $(\mathrm{F} / \mathrm{Fr})$ transformation rates. Capital letters compare two periods of the same area and lowercase letters, two areas in a same period. Values followed by different letters presented significant differences $(\mathrm{p}<0.05)$.

Tabela 2 - Produção de botões, flores e frutos (média \pm erro padrão) por inflorescência de Anacardium humile. Taxa de frutificação de botões para flores $(B / F)$, de botões para frutos $(B / F r)$ e de flores para frutos $(F / F r)$. Letras maiúsculas comparam dois períodos de uma mesma área e letras minúsculas, duas áreas em um mesmo periodo. Valores seguidos de letras diferentes apresentam diferenças significativas $(p<0,05)$.

\begin{tabular}{|c|c|c|c|c|}
\hline & \multicolumn{2}{|c|}{2016} & \multicolumn{2}{|c|}{2017} \\
\hline & Control & Burned & Control & Burned \\
\hline Buds & $186.38 \pm 28.47 \mathrm{a}, \mathrm{A}$ & $253.14 \pm 37.04 \mathrm{~b}, \mathrm{~A}$ & $171.83 \pm 12.60 \mathrm{a}, \mathrm{A}$ & $171.17 \pm 14.51 \mathrm{a}, \mathrm{B}$ \\
\hline Flowers & $50.81 \pm 12.62 \mathrm{a}, \mathrm{A}$ & $93.20 \pm 19.89 \mathrm{~b}, \mathrm{~A}$ & $48.55 \pm 5.15 \mathrm{a}, \mathrm{A}$ & $49.40 \pm 4.53 \mathrm{a}, \mathrm{B}$ \\
\hline Fruits & $0.37 \pm 0.13 \mathrm{a}, \mathrm{A}$ & $0.39 \pm 0.39 \mathrm{a}, \mathrm{A}$ & $2.15 \pm 0.54 \mathrm{a}, \mathrm{B}$ & $1.96 \pm 0.38 \mathrm{a}, \mathrm{B}$ \\
\hline $\mathrm{B} / \mathrm{F}(\%)$ & $27 \mathrm{a}, \mathrm{A}$ & $36 \mathrm{~b}, \mathrm{~A}$ & $28 \mathrm{a}, \mathrm{A}$ & 29 a,A \\
\hline $\mathrm{B} / \mathrm{Fr}(\%)$ & $0.20 \mathrm{a}, \mathrm{A}$ & $0.15 \mathrm{a}, \mathrm{A}$ & $1.25 \mathrm{a}, \mathrm{B}$ & $1.15 \mathrm{a}, \mathrm{B}$ \\
\hline $\mathrm{F} / \mathrm{Fr}(\%)$ & $0.73 \mathrm{a}, \mathrm{A}$ & $0.42 \mathrm{a}, \mathrm{A}$ & $4.43 \mathrm{a}, \mathrm{B}$ & $3.97 \mathrm{a}, \mathrm{B}$ \\
\hline
\end{tabular}


In the control area, the production of floral bud, flower and fruit did not differ between the years (Table 1), but fruit production per panicle was higher in 2017 (Table 2 ). The buds to flowers transformation rate was not significantly different between the years (around 28\%), on the other hand, buds to fruits and flowers to fruits transformation rates increased significantly (Table 2), starting at $0.20 \%$ and $0.73 \%$ in 2016 , to $1.25 \%$ and $4.43 \%$ in 2017 , respectively.

In the burned area, the production of floral bud, flower and fruit were significantly higher when considering the total average number produced (Table 1), and lower when considered per panicle (Table 2), between 2016 and 2017. The buds to flowers transformation rate, despite higher in 2016 (36\%), did not differ significantly from the rate found in 2017 (29\%). However, the buds to fruits and flowers to fruits transformation increased significantly between the years, from $0.15 \%$ and $0.42 \%$ in 2016 , to $1.15 \%$ and $3.97 \%$ in 2017 , respectively.

\section{DISCUSSION}

Individuals located in the area submitted to the controlled burning in May 2016 had some branches burned, but without occurrences of total combustion of the branch. In general, the fire caused dehydration of plant tissues (stem and leaves), and subsequent senescence of the branches. Approximately ten days after burning, all individuals had basal regrowth in some areas. This level of damage severity and fire response is related, on the one hand, to the amount of fuel available, topography and climatic conditions (Whelan, 1995; Bigler et al., 2005; Miranda and Sato, 2005) and on the other, to the characteristics inherent to the species such as size, architecture, phenology, reproductive success, mechanisms tissues protection and reproduction (Hoffman, 1998; Garcia Nuñez et al., 2001; Lucena et al., 2015; Sato et al., 2018).

Individuals size in relation to the flames height influences the damages suffered (Miranda and Sato, 2005; Sato et al., 2018), and it is generally reported that during the year of burning, woody species in the reproductive period present a drastic reduction of fruiting while for tree species, production may be larger, smaller or indifferent (Sanaiotti and Magnusson, 1995; Miranda, 1995; Hoffman, 1998; Felfili et al., 1999; Schmidt et al., 2005; Palermo and Miranda, 2012; Françoso et. al., 2014; Lucena et al., 2015).
In the reproductive period of 2016, while individuals in the burned area invested energy in the production of new vegetative structures, individuals in the control area were already producing buds and flowers, which resulted in greater production, including fruits, in the latter area. The energy expenditure with the production of new branches (Hoffman, 1998; Felfili et al., 1999; Palermo and Miranda, 2012) during the period of sexual reproduction of $A$. humile caused $81 \%$ of the individuals not to bloom.

Still regarding 2016, larger productions of buds and flowers per panicle in the burned area may have been favored by the greater availability of light and nutrients such as calcium, phosphorus and nitrogen on the soil surface soon after burning (Kellman, 1984; Kauffman et al., 1997) and neutralization of soil acidity by means of ash (Costa and Rodrigues, 2015). The reproductive effort of individuals in the burned area was higher when compared to the control area, even with less loss of buds before developing flowers, $64 \%$ before to $74 \%$ of the control area. On the other hand, the absence of difference in fruiting rate between the areas demonstrates that this effort was not efficient for a higher production of fruits, as observed by Palermo and Miranda (2012) for the arboreal species Qualea parviflora (Mart.). It is also likely that the number of pollinators in the burned area has been negatively affected by fire, as observed in areas burned by Felfili et al. (1999), Potts et al. (2003), Miola et al. (2010) e Giehl et al. (2013).

One year after the fire, there was no difference in the number of individuals blooming and in the production of flower buds, flowers and fruits between the control and burned area. With fully developed branches, the production of structures linked to sexual reproduction in the burned area has returned to the expected patterns for the species, indicating that fire has a more immediate effect within the reproductive period of species than in the longer term. Similar results were also found for woody species in Cerrado stricto sensu areas such as Kielmeyera coriacea Mart. \& Zucc, Stryphnodendron adstringens (Mart.) Coville, Roupala montana Aubl and Schefflera vinosa (Cham. \& Schltdl.) Frodin \& Fiaschi (Landim and Hay, 1996; Hoffmann, 1998; Felfili et al., 1999; Dodonov et al., 2018).

The opposite was observed for Qualea parviflora e Piptocarpha rotundifolia (Less.) Baker, that showed high production of flowers after fire and no or low

Revista Árvore. 2018;42(6):e420605 
flowering in subsequent years, probably due to energy expenditure of the first flowering and replacement of vegetative parts lost during the fire (Hoffman, 1998; Palermo and Miranda, 2012). When comparing the effect of fire, after one year, on the shrubs Miconia albicans (SW) Steud and Schefflera vinosa, Dodonov et al. (2018) concluded that although they had similar characteristics such as size, phenology and architecture, the fire effect on reproductive phenology differed, probably due to their growth rate and their ability to store seeds in the soil. For them, the fact that $S$. vinosa does not occur in the seed bank and the need to originate new individuals through production and dispersion of new propagules, caused this specimen to develop more intense post-fire flowering in comparison to M. albicans. In the present study, despite similar production between the areas, in 2017 the reproductive period extended more in the control area (May to October) than in the burned area (May to September), indicating an effect of the disturbance caused by fire on these specimens flowering.

The significant increase in the number of individuals blooming in the area burned in 2017 in comparison to 2016 shows that one year after the fire, this species can already recover its reproductive potential. The higher fruit production in 2017 comparison to 2016 in both burned and control areas suggests that the species presents variation between reproductive periods. This variation may be related to the need for more flowering resources than can be generally acquired in one year, forcing individuals to reproduce in alternate years or at longer and irregular intervals (Satake and Iwasa, 2000, 2002). This variable pattern in fruit production has also been observed for Annona crassiflora Mart (Braga Filho et al., 2009) and Caryocar brasiliense Camb. (Ferreira et al., 2015) in the Cerrado. Species that exhibit this pattern may have greater losses when fire occurs in the year of greatest production, since there will be greater loss of reproductive structures (Whelan, 1995; Palermo and Miranda, 2012).

Even with higher fruit production in both areas in 2017 , the flowers to fruits transformation rate around $4 \%$ can be considered low when compared to the $80 \%$ found for Q. parviflora (Palermo and Miranda, 2012), $25 \%$ to $40 \%$ found for Rourea induta Planch (Lenza et al., 2008) and 36\% and 60\% for Byrsonima umbellata Mart. ex A. Juss. and B. rotunda Griseb. (Mendes et al., 2011). The fruiting rate found for $A$. humile suggests low reproductive potential, corroborating Ferrão (1995) when reporting that this species produces many flowers and few fruits. According to the author this is due to: (1) the existence of limitations on pollination, such as the inability of some hermaphrodite flowers to become fruit, (2) the tendency of pollen grains of stamens to remain attached to the anther after dehiscence, (3) and the fact that in staminate flowers only one out of eight to ten stamens is fertile. Almeida et al. (1998) attributes the species low fruit production to a ratio of 4: 1 between staminate and hermaphrodite flowers. Anacardium occidentale L., a species related to A. humile, also presents a low percentage of fruits formed in comparison to the number of perfect flowers produced $(<10 \%)$ (Pinheiro et al., 1993; Sousa et al., 2007). Despite the low efficiency in sexual reproduction, asexual reproduction is frequent in A. humile (Sousa and Cunha, 2018) and can be used by species as a survival strategy in case of high frequency of fires (Hoffman, 1998). However, despite the low reproductive potential, the high genetic variability found for $A$. humile individuals (Carvalho et al., 2012; Pereira etal., 2016) evidences the importance of sexual reproduction in the population maintenance of the species.

\section{CONCLUSION}

It is important to emphasize that this study shows results of first-order fire effects, performed in mid-May, early dry season in Cavalcante-GO, while the specimens began their reproductive period. We conclude that the effect of the controlled burning on flowering and fruiting of $A$. humile is greater and negative in the same year of the fire. One year after fire, the production of flowers and fruits is similar between areas, differing only in the phenomena synchrony between them. We believe that by decreasing the number of individuals blooming during the year of burning, the fire compromises even more the low efficiency of $A$. humile sexual reproduction and stimulates asexual reproduction through the emission of new basal shoots. If frequent, fire occurrence may have a negative effect even in asexual reproduction, putting at risk the population survival. Thus, it is interesting to evaluate how early, mid- and late dry season fires affect the sexual and asexual reproduction of $A$. humile during a longer follow-up period.

\section{ACKNOWLEDGMENTS}

D.G.S thanks IBAMA for license granted to attend the PPGSS RENAC/UEG, FAPEG for scholarship process $\mathrm{n}^{\mathrm{o}} 201610267000635$, awarded during Master's and the 
Brigada Kalunga de Prevenção e Combate aos Incêndios Florestais (IBAMA/PREVFOGO) for support in field work. H.F.C thanks CNPq for research productivity fellowship (Process n. 302198/2015-6).

\section{REFERENCES}

Agostini-Costa TS, Faria JP, Naves RV, Vieira RF. Anacardium spp. In: Vieira RF, Camilo J, Coradin L, editores. Espécies nativas da flora brasileira de valor econômico atual ou potencial: Plantas para o Futuro: Região Centro-Oeste. Brasília, DF: Ministério da Agricultura; 2016. p.138-49.

Almeida SP, Proença CEB, Sano SM, Ribeiro JF. Cerrado: espécies vegetais úteis. Planaltina: Embrapa; 1998. 464p.

Andrade LFD. O papel do fogo na germinação das sementes de leguminosas do Cerrado [tese]. Rio Claro: Universidade Estadual Paulista; 2017.

Arruda FV, Sousa DG, Teresa FB, Prado VHM, Cunha HF, Izzo TJ. Trends and gaps of the scientific literature about the effects of fire on Brazilian Cerrado. Biota Neotropica. 2018;1:1-6.

Bigler C, Kulakowski D, Veblen TT. Multiple disturbance interactions and drought influence fire severity in Rocky Mountain subalpine forests. Ecology. 2005;86(11):3018-29.

Bouchartdet DA, Ribeiro IM, Souza NA, Aires SS, Miranda HS. Efeito de altas temperaturas na germinação de sementes de Plathymenia reticulata Benth. e Dalbergia miscolobium Benth. Revista Árvore. 2015;39(4):697-705.

Braga Filho JR, Naves RV, Veloso VRS, Chaves LJ, Nascimento JL, Aguiar AV. Produção de frutos e caracterização de ambientes de ocorrência de plantas nativas de araticum no cerrado de Goiás. Revista Brasileira de Fruticultura. 2009;31(2):461-73.

Carvalho MP, Santana DG, Ranal MA. Emergência de plântulas de Anacardium humile A. St.-Hil. (Anacardiaceae) avaliada por meio de amostras pequenas. Brazilian Journal of Botany. 2005;28(3):627-33.

Carvalho RS, Pinto JFN, Reis EF, Santos SC, Dias LAS. Variabilidade genética de cajuzinho-do- cerrado (Anacardium humile St. Hill.) por meio de marcadores rapd. Revista Brasileira de Fruticultura. 2012;34(1):227-33.

Cirne P, Miranda HS. Effects of prescribed fires on the survival and release of seeds of Kielmeyera coriacea (Spr.) Mart. (Clusiaceae) in savannas of Central Brazil. Brazilian Journal of Plant Physiology. 2008;20(3):197-204.

Costa YT, Rodrigues SC. Efeito do fogo sobre vegetação e solo a partir de estudo experimental em ambiente de cerrado. Revista do Departamento de Geografia. 2015;30:149-65

Deus FF, Oliveira PM. Changes in floristic composition and pollination systems in a "Cerrado" community after 20 years of fire suppression. Brazilian Journal of Botany. 2016;39(4):1051-63.

Dodonov P, Zanelli CB, Silva-Matos DM. Effects of an accidental dry-season fire on the reproductive phenology of two Neotropical savanna shrubs. Brazilian Journal of Biology. 2018;78(3):564-73.

Durigan G, Ratter JA. The need for a consistent fire policy for Cerrado conservation. Journal of Applied Ecology. 2016;53:11-15.

Empresa Brasileira de Pesquisa Agropecuária Embrapa. Sistema Brasileiro de Classificação de Solos. $2^{\mathrm{a}}$ ed. Rio de Janeiro: Embrapa Solos; 2006. $306 \mathrm{p}$.

Felfili JM, Silva-Junior MC, Dias BJ, Rezende AV. Estudo fenológico de Stryphnodendron adstringens (Mart.) Coville no cerrado sensu stricto da Fazenda Água Limpa no Distrito Federal, Brasil. Brazilian Journal of Botany. 1999;22:83-90.

Ferrão JEM. O cajueiro (Anacardium occidentale L.). Lisboa: Instituto de Investigação Cientifica Tropical; 1995. 298p.

Ferreira GA, Naves RV, Chaves LJ, Veloso VR, Souza ERB. Produção de frutos de populações naturais de pequizeiro no estado de Goiás. Revista Brasileira de Fruticultura. 2015;37:121-29.

Revista Árvore. 2018;42(6):e420605 
Fiedler NC, Azevedo INC, Rezende AV, Medeiros MB, Venturoili F. Efeito de incêndios florestais na estrutura e composição florística de uma área de cerrado sensu strictu na Fazenda Água Limpa DF. Revista Árvore. 2004;28(1):129-38.

Françoso R, Guaraldo AC, Prada M, Paiva AO, Mota EH, Pinto JRR. . Fenologia e produção de frutos de Caryocar brasiliense Cambess. e Enterolobium gummiferum (Mart.) J.F.Macbr. em diferentes regimes de queima. Revista Árvore. 2014;38(4):579-90.

Fundação Grupo Boticário. Plano de Manejo da Reserva Natural Serra do Tombador. Supervisão de G. A. Gatti. Curitiba: 2011. [acessado em: 28 maio de 2017]. Disponível em: http:// www.fundacaogrupoboticario.org.br

García-Núñez C, Azócar A, Silva JF. Seed production and soil seed bank in three evergreen woody species from a neotropical savanna. Journal of Tropical Ecology. 2001;17(4):563-76.

Giehl NFS, Valadão MBX, Brasil LS, Sabtos JO, Almeida SM, Lenza E, et al. O efeito do fogo sobre a comunidade de abelhas Euglossini (Hymenoptera: Apidae) em Floresta de Transição Cerrado-Amazônia (Mato Grosso, Brasil). EntomoBrasilis. 2013;6:178-83.

Gomes L, Miranda HS, Bustamante MMC. How can we advance the knowledge on the behavior and effects of fire in the Cerrado biome?. Forest Ecology and Management. 2018;417:281-90.

Hoffmann WA. Post-burn reproduction of woody plants in a neotropical savanna: the relative importance of sexual and vegetative reproduction. Journal of Applied Ecology. 1998;35(3):422-33.

Kauffman JB, Sapsis DB, Till KM. Ecological studies of fire in sagebrush/bunchgrass ecosystems of the John Day Fossil Beds National Park, Oregon: implications for the use of prescribed burning to maintain natural ecosystems. Washington, DC: National Park Service, Columbia Cascades System Support Office; 1997. 148p.

Kellman M. Synergistic relationships between fire and low soil fertility in neotropical Savannas: A Hypothesis. Biotropica. 1984;16(2):158-60.
Landim MF, Hay JD. Impacto do fogo sobre alguns aspectos da biologia reprodutiva de Kielmeyera coriacea Mart. Revista Brasileira de Biologia. 1996;56:127- 34.

Lenza E, Ferreira JN, Consolaro H, Aquino FG. Biologia reprodutiva de Rourea induta Planch. (Connaraceae), uma espécie heterostílica de cerrado do Brasil Central. Revista Brasileira de Botânica. 2008;31:389-98.

Loiola PD, Cianciaruso MV, Silva IA, Batalha MA . Functional diversity of herbaceous species under different fire frequencies in Brazilian savannas. Flora. 2010;205(10):674-81.

Lucena IC, Leite MB, Matos DMS. A deciduidade foliar indica a vulnerabilidade de espécies lenhosas ao fogo. Revista Árvore. 2015;39(1):59-68.

Medeiros MB, Fiedler NC. Incêndios florestais no Parque Nacional da Serra da Canastra: Desafios para a conservação da biodiversidade. Ciência Florestal. 2004;14:157-68.

Medeiros MB, Miranda HS. Mortalidade pós-fogo em espécies lenhosas de campo sujo submetidas a três queimadas prescritas anuais. Acta Botanica Brasilica. 2005;19(3):493-500.

Mendes FN, Rêgo MMC, Albuquerque, PMC. Fenologia e biologia reprodutiva de duas espécies de Byrsonima Rich. (Malpighiaceae) em área de Cerrado no Nordeste do Brasil. Biota Neotropica. 2011;11:103-15.

Mendiburu F. agricolae: Statistical Procedures for Agricultural Research. R package version 1.2-4. 2016. [acessado em: 01 out. 2017]. Disponível em: https:/CRAN.R-project.org/ package $=$ agricolae.

Miola DTB, Correia HVL, Fernandes GW, Negreiros D. Efeito do fogo na fenologia de Syagrus glaucescens Glaz. ex Becc. (Arecaceae). Neotropical Biology and Conservation. 2010;5:146-53.

Miranda HS, Sato MN. Efeitos do fogo na vegetação lenhosa do Cerrado. In: Scariot A, Souza-Silva JC, Felfili JM, editores. Cerrado: ecologia, biodiversidade e conservação. Brasília: Ministério do Meio Ambiente; 2005. p.92-104. 
Miranda IS. Fenologia do estrato arbóreo de uma comunidade de cerrado em Alter-do-Chão, Pará. Revista Brasileira de Botânica. 1995;18(2):235-40.

Myers N, Mittermeier RA, Mittermeier CG, da Fonseca GAB, Kent J. Biodiversity hotspots for conservation priorities. Nature. 2000;403:853-58.

Myers RL. Convivendo com o fogo manutenção dos ecossistemas e subsistência com o manejo integrado do fogo. Tradução de Margaret Batalha. Tallahassee: The Nature Conservancy - Iniciativa Global para o Manejo do Fogo; 2006. 30p.

Palermo AC, Miranda HS. Efeito do fogo na produção de frutos de Qualea parviflora MART. (Vochysiaceae) em Cerrado sensu stricto. Revista Árvore. 2012;36(4):685-93.

Pereira LD, Costa ML, Naves Pinto JF, Assunção $H F$, Reis EF, Silva DFP. Diversidade genética do florescimento de Anacardium humile A. St. Hill. no sudoeste goiano. Revista Brasileira de Agropecuária Sustentável. 2016;6:19-25.

Pinheiro FFM, Crisostomo JR, Parente JIG, Melo FIO. Desenvolvimento de caracteres da panícula e frutificação de duas populações de cajueiros comum e anão precoce (Anacardium occidentale). Fortaleza: Embrapa-CNPCa; 1993. 24p.

Potts SG, Vulliamy B, Dafni A, O'Toole C, Roberts $\mathrm{S}$, Willmer P. Response of plant-pollinator communities to fire: changes in diversity, abundance and floral reward structure. Oikos. 2003;101:103-12.

R Core Team. R: A language and environment for statistical computing, R Foundatiton for Statistical Computing, Vienna, Austria. 2016. [acessado em: 22 maio de 2017]. Disponível em https://www.Rproject.org/

Ramos Neto MB, Pivello VR. Lightning Fires in a Brazilian Savanna National Park: Rethinking Management Strategies. Environmental
Management. 2000;26:675-84.

Rawitscher FK, Ferri MG, Rachid M. Profundidade dos solos e vegetação em campos cerrados do Brasil Meridional. Anais da Academia Brasileira de Ciências. 1943;15:267-94.

Salgado-Labouriau ML, Ferraz-Vicentini KR. Fire in the Cerrado 32,000 years ago. Current Research in the Pleistocene. 1994;11:85-87.

Sanaiotti TM, Magnusson WE. Effects of annual fires on the production of fleshy fruits eaten by birds in a Brazilian Amazonian savanna. Journal of Tropical Ecology. 1995;11:53-65.

Satake A, Iwasa Y. Spatially limited pollen exchange and a long range synchronization of trees. Ecology. 2002;90:830-33

Satake A, Iwasa Y. Pollen coupling of forest trees: forming synchronized and periodic reproduction out of chaos. Journal of Theoretical Biology. 2000;203:63-84.

Sato M, Musso C, Miranda, HS. Fire-induced damage to Qualea multiflora Mart. seeds depends on fruit protection and the position in the tree crown. Plant Biology. 2018;20(6):1036-41.

Schmidt IB, Sampaio AB, Borghetti F. Efeitos da época de queima sobre a reprodução sexuada e estrutura populacional de Heteropterys pteropetala (Adr. Juss.), Malpighiaceae, em áreas de Cerrado sensu stricto submetidas a queimas bienais. Acta Botanica Brasilica. 2005;19(4):927-34.

Sousa DG; Cunha HF. Population structure, spatial distribution and phenology of Anacardium humile A. St.-Hil. (Anacardiaceae) in cerrado stricto sensu. Hoehnea. 2018;45(3):450-67.

Sousa LB, Feitoza LL, Gomes RLF. Aspectos de biologia floral de cajueiros anão precoce e comum. Ciência Rural. 2007;37:882-85.

Whelan RJ. The ecology of fire. London: Cambridge University Press; 1995. 346p. 